DOI

\title{
ТРОМБОЦИТАРНО-ЕНДОТЕЛІАЛЬНА МОЛЕКУЛА АДГЕЗІЇ ЯК ПРЕДИКТОР ДИСФУНКЦІї ЕНДОТЕЛІЮ ПРИ АРТЕРІАЛЬНІЙ ГІПЕРТЕНЗІЇ З ЦУКРОВИМ ДІАБЕТОМ ІІ ТИПУ
}

๑є. І. Шоріков

\section{Вищий державний навчальний заклад України «Буковинський державний медичний університет»}

РЕЗЮМЕ. В статті розглядається роль тромбоцитарно-ендотеліальної молекули адгезії sРЕСАМ-1 в патогенезі дисфункції ендотелію у хворих на гіпертонічну хворобу з цукровим діабетом II типу.

Встановлено вірогідний кореляційний зв'язок між концентрацією SPECAM-1, параметрами вуглеводного обміну та моделлю НOMA-IR. Зниження коефіцієнтів розтяжності, відносної деформації, локальної жорсткості та збільшення швидкості розповсюдження пульсової хвилі супроводжується підвищеною експресією молекули адгезії. Верифіковано позитивний зв'язок між концентрацією SPECAM-1 та напругою зсуву в пробі з ендотелійзалежною вазодилатацією, негативний зв'язок - між збільшенням вмісту SPECAM-1 та чутливістю ендотелію до вазодилатації. Проаналізовано діагностичну цінність рівня тромбоцитарно-ендотеліальної молекули адгезії SPECAM-1 для прогнозування дисфункції ендотелію.

КЛЮчОВІ СЛОВА: дисфункція ендотелію, гіпертонічна хвороба, цукровий діабет, молекула адгезії, SPECAM-1.

Вступ. В патогенезі ендотеліальної дисфункції (ЕД) важливе місце займають зміни адгезивних властивостей судинної стінки. Клітинний контакт при цьому забезпечується суперсімейством глікопротеїнів, яке називають молекулами міжклітинної адгезії. Воно включає у себе сімейства селектинів, інтегринів, специфічних імуноглобулінових рецепторів, кадгеринів, хомінгових рецепторів. У патологічних умовах, коли змінюється напруга зсуву на ендотелії, збільшується експресія молекул адгезії. Доведена роль підвищення вмісту розчинних форм Е- та Р-селектинів, ICAM-1 та VCAM-1 в розвитку судинних та тромбогенних ускладнень артеріальної гіпертензії (АГ) [4], в порушенні мікроциркуляції та патологічному ангіогенезі [14], в розвитку ангіопатій при цукровому діабеті (ЦД) [11].

sPECAM-190 (soluble platelet endothelial cell ahesion molecule-1) $\epsilon$ розчинною формою глікопротеїну, відомою під назвою CD31. У ряді досліджень доведена участь цієї молекули в процесах тромбоутворення [12], проте рівень їі експресії не залежить від рівня тромбіну та тромбомодуліну [7]. Доведено, що рівень SPECAM-1 у крові асоціюється з подовженим часом розсмоктування тромбу та підвищеною експресією молекули на поверхні судин під час тромбоутворення. У ряді досліджень вивчено участь SPECAM-1 в механосенсорному каскаді [10], в інших [9] вказується на роль цієї молекули у розвитку механосенсорної відповіді при атеросклерозі. Експериментальними роботами доведено, що SPECAM-1 сприяє розвитку атеросклеротичного ураження судин шляхом підсилення міграції лейкоцитів, причому підвищений рівень ліпопротеїдів низької щільності безпосередньо забезпечує систему ап-регуляції CD31 в ендотеліальних клітинах [6]. Враховуючи дослідження хворих із наявністю супутнього ЦД ІІ, важливими $\epsilon$ експериментальні роботи, що свідчать про стимуляцію SPECAM-1-залежного шляху міграції моноцитів та активації тромбоцитів підвищенним вмістом глюкози та інсуліну [13].

Таким чином, враховуючи різноманітність механізмів, які пов'язують розчинну форму CD31 із ангіогенезом, механорецепцією, тромбогенним потенціалом, процесами запалення судинної стінки, актуальним $\epsilon$ дослідження ролі SPECAM-1 В розвитку дисфункції ендотелію у хворих на АГ асоційовану з ЦД II типу.

Мета роботи: вивчити ступінь експресії молекули адгезії sPECAM-1, враховуючи ступінь ураження органів-мішеней, тип ендотелійзалежної вазодилатації, показники вуглеводного обміну, жорсткість судинного русла.

Матеріал і методи дослідження. Було о6стежено 146 хворих на гіпертонічну хворобу (ГХ), серед яких був 101 хворий з коморбідністю за ЦД II типу. Середній вік - $(55,7 \pm 10,3)$ року. Для верифікації стадії ГХ використовували рекомендації Української асоціації кардіологів, Європейського товариства гіпертензії та кардіології [3], а також Європейської асоціації з вивчення цукрового діабету [5]. Окрім того, було обстежено 35 практично здорових осіб.

Рівень SPECAM-1 (Bender MedSystems, USA) визначали шляхом твердофазного імуноферментного аналізу, заснованого на «сендвіч»-методі. Дослідження проводили на імуноферментному аналізаторі Rayto-2100C (China).

Дослідження протокозалежної вазодилатації (ендотелійзалежної, ЕЗВД) здійснювали шляхом використання апарату «EnVisor HD» (Philips, USA) за методикою D. Celermajer, K. E. Sorensen [8] у модифікації В. Г. Лелюк [1]. Показники жорсткості аорти на 
Огляди літератури, оригінальні дослідження, погляд на проблему

рівні висхідного відділу (Rv) та дуги (Rd), загальної сонної (ЗСA), плечової та стегнової артерій визначали за методикою В. Г. Лелюк [1]. Серед параметрів локальної жорсткості та еластичності розраховували наступні: 1) DC - індекс розтягнення, що характеризує відносну зміну поперечного перерізу судини на одиницю тиску; 2) Ер - модуль еластичності Петерсона - здатність до відновлення стінки артерії до вихідного стану; 3) $\beta$-індекс жорсткості; 4) OPPWV швидкість пульсової хвилі, що виміряна методом «однієї точки»; 5) LS - деформація просвіту судини, що відображає зміну об'єму в систолі.

Результати дослідження представлені у вигляді медіани та 25-75 процентилів. Аналіз даних проводили із використанням непараметричної ANOVA за Крускал-Уолісом та непараметричної кореляції за Спірменом. Для статистичного аналізу отрима- них результатів використовували пакет програм обробки даних загального призначення Statistica for Windows вepciï 6.0 (Stat Soft inc., США) [2].

Результати й обговорення. У хворих на ГХ та ЦДІІтипу було виявлено вірогідний приріст $(p<0,05)$ CD31. У практично здорових осіб вміст SPECAM-1 складав - 42,23 $(37,23-54,34)$ нг/мл. Концентрація CD31 у крові хворих на АГ із супутнім ЦД ІІ характеризувалась великим розмахом коливань значень та становила 85,63 $(47,95-110,77)$ нг/мл, відповідно у хворих на ізольовану АГ - 49,63 $(37,46-68,12)$ нг/мл (рис. 1), $p<0,001$.

Залежність вмісту SPECAM-1 у крові хворих на АГ від супутнього ЦД II підтверджується результатами кореляційного аналізу між його концентрацією, параметрами вуглеводного обміну та моделлю HOMA-IR (табл. 1).

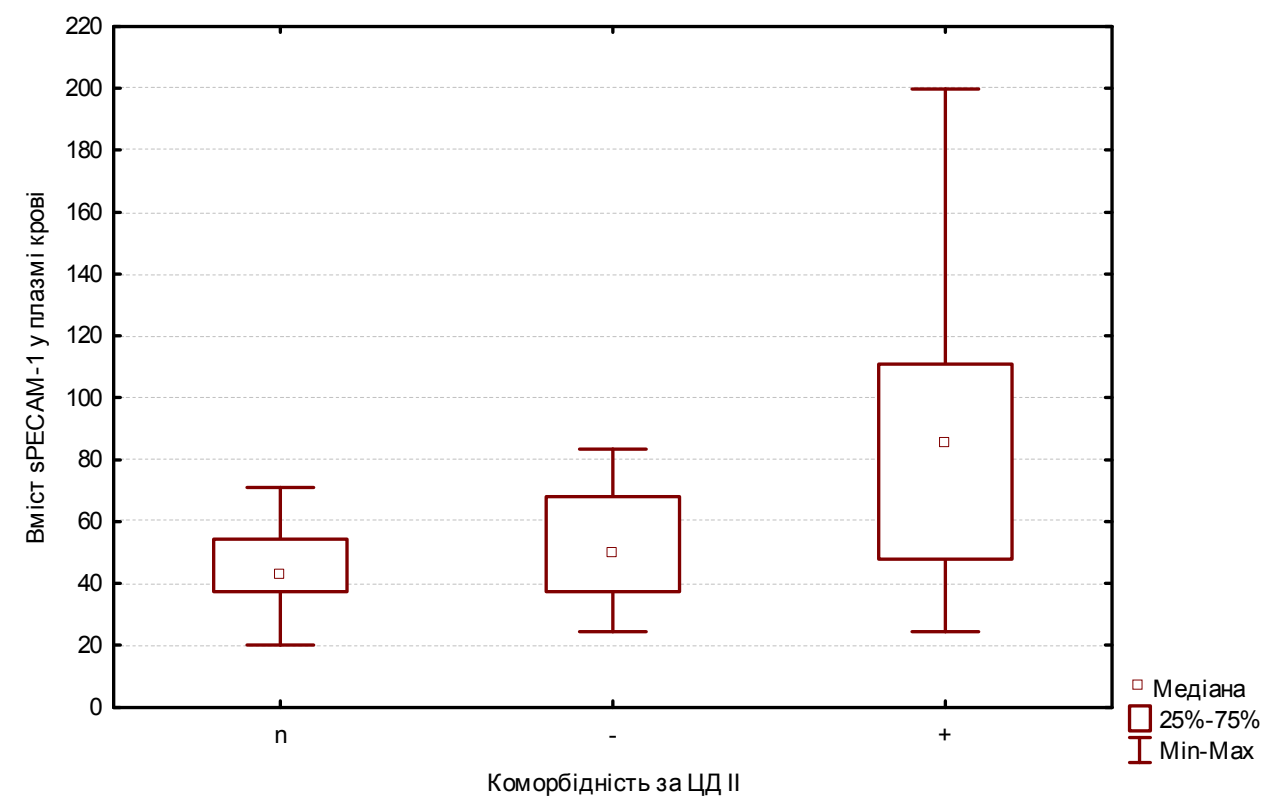

Рис. 1. Вміст SPECAM-1 у плазмі хворих на АГ залежно від коморбідності за ЦД ІІ типу.

Таблиця 1. Взаємозв'язок між вмістом SPECAM-1 та станом вуглеводного обміну (R-кореляція Спірмена) у хворих на АГ та ЦД ІІ типу

\begin{tabular}{|c|c|c|c|}
\hline Показники & Глюкоза & Інсулін & HOMA IR \\
\hline Вміст & $R=0,18$ & $R=0,35$ & $R=0,33$ \\
SPECАM-1 & $(p=0,058)$ & $(p=0,002)$ & $(p=0,004)$ \\
\hline
\end{tabular}

Наступним завданням було дослідити асоціацію між експресією SPECAM-1 та показниками розтяжності аорти (табл. 2). Встановлено негативний вірогідний кореляційний зв'язок середньої сили на рівні висхідної частини аорти $(p<0,05)$ та дуги $(p=0,07)$.

Таблиця 2. Взаємозв'язок між ступенем розтяжності аорти та вмістом sPECAM-1 (R-кореляція Спірмена) у хворих на АГ та ЦД ІІ типу

\begin{tabular}{|c|c|c|}
\hline Показники & $\mathrm{Rv}$ & $\mathrm{Rd}$ \\
\hline Вміст SPECAM-1 & $\mathrm{R}=-0,44$ & $\mathrm{R}=-0,27$ \\
& $(p=0,01)$ & $(p=0,07)$ \\
\hline
\end{tabular}


Огляди літератури, оригінальні дослідження, погляд на проблему

При аналізі взаємодії між експресією ливістю на рівні загальних сонних (ЗСА), плечоSPECAM-1, розтяжністю, еластичністю, індексом вих (ПА) та стегнових артерій (СА) були отримані жорсткості, швидкістю пульсової хвилі та піддат- результати, що представлені в таблиці 3.

Таблиця 3. Взаємозв'язки між вмістом SPECAM-1 та локальною жорсткістю ЗСА, ПА та СА у хворих на АГ та ЦД ІІ типу

\begin{tabular}{|c|c|c|c|c|c|c|}
\hline Показники & DC 3CA & CC 3CA & EP 3CA & $\beta 3 C A$ & LS 3CA & OPPWV 3CA \\
\hline ВMіст SPECAM-1 & $\begin{array}{l}R=-0,48 \\
p=0,003\end{array}$ & $\begin{array}{l}R=-0,13 \\
p=0,44\end{array}$ & $\begin{array}{l}R=0,48 \\
p=0,003\end{array}$ & $\begin{array}{l}R=0,47 \\
p=0,004\end{array}$ & $\begin{array}{l}R=-0,46 \\
P=0,005\end{array}$ & $\begin{array}{l}R=0,42 \\
p=0,01\end{array}$ \\
\hline Показники & $\mathrm{DC} \sqcap \mathrm{A}$ & ССПА & ЕР ПА & $\beta \sqcap A$ & LS ПA & OPPWV ПА \\
\hline ВMіст SPECAM-1 & $\begin{array}{l}R=-0,48 \\
p=0,004\end{array}$ & $\begin{array}{l}R=-0,30 \\
p=0,07\end{array}$ & $\begin{array}{c}R=0,46 \\
p=0,005\end{array}$ & $\begin{array}{c}R=0,47 \\
p=0,004\end{array}$ & $\begin{array}{l}R=-0,46 \\
p=0,006\end{array}$ & $\begin{array}{l}R=0,42 \\
p=0,01\end{array}$ \\
\hline Показники & DC ФA & CС ФA & ЕР ФA & $\beta \Phi A$ & LS ФA & OPPWV ФA \\
\hline ВMіст SPECAM-1 & $\begin{array}{l}R=-0,40 \\
p=0,016\end{array}$ & $\begin{array}{l}R=-0,43 \\
p=0,01\end{array}$ & $\begin{array}{c}R=0,43 \\
p=0,009\end{array}$ & $\begin{array}{l}R=0,36 \\
p=0,03\end{array}$ & $\begin{array}{l}R=-0,36 \\
p=0,03\end{array}$ & $\begin{array}{l}R=0,40 \\
p=0,02\end{array}$ \\
\hline
\end{tabular}

Зокрема, у хворих на АГ з ЦД ІІ типу на тлі підвищеної експресії тромбоцитарно-ендотеліальної молекули адгезії спостерігаються істотне зниження коефіцієнтів розтяжності $(p<0,05)$ та піддатливості артерій еластичного типу, зменшення показника відносної деформації $(p<0,05)$ судинного просвіту з одночасним зростанням величини модуля еластичності $(p<0,05)$, коефіцієнта локальної жорсткості $(p<0,05)$ та збільшення швидкості розповсюдження пульсової хвилі $(p<0,05)$.

Після проведення кореляційного аналізу між вмістом розчинної форми CD31 та ключовими параметрами проби з реактивною гіперемією встановлено позитивний зв'язок середньої сили 3 достатньою мірою достовірності $(p=0,08)$ між концентрацією SPECAM-1 та величиною напруги зсуву $\left(\tau_{0}\right)$, вірогідну $(p=0,04)$ залежність між вмісTом SPECAM-1 та абсолютним зниженням приросту діаметра у пробі із вазодилатацією, а також доволі вірогідну взаємозалежність $(p=0,09)$ між збільшеним рівнем експресії sPECAM-1 та зниженням чутливості до вазодилатації (К) (табл. 4).

Отже, проведене дослідження свідчить про те, що надмірна експресія SPECAM-1 $\epsilon$ чутливим індикатором змін механічних параметрів судин, залежних від стану ендотелію та медіального шару. Тому перед нами постало завдання оцінити, по-перше, чи існує безпосередній зв'язок між експресією SPECAM-1 та параметрами ремоделювання артерій та серцевого м'яза, i, по-друге, яке діагностичне значенння має вміст SPECAM-1 у якості маркера ендотеліальної дисфункції.

Таблиця 4. Взаємозв'язок між вмістом SPECAM-1 та показниками проби з ендотелійзалежною вазодилатацією у хворих на АГ та ЦД ІІ типу

\begin{tabular}{|c|c|c|c|c|}
\hline Показники & Приріст $\mathrm{D}_{0}$ & $\tau_{0}$ & Приріст $\Delta \tau_{0} \%$ & $\mathrm{~K}$ \\
\hline Вміст SPECAM-1 & $\begin{array}{c}\mathrm{R}=-0,47 \\
(\mathrm{p}=0,04)\end{array}$ & $\mathrm{R}=0,39(\mathrm{p}=0,08)$ & $\mathrm{R}=-0,03(\mathrm{p}=0,86)$ & $\begin{array}{c}\mathrm{R}=-0,36 \\
(\mathrm{p}=0,09)\end{array}$ \\
\hline
\end{tabular}

Для вирішення наступного завдання - оцінки порогової концентрації SPECAM-1 для діагностики ендотеліальної дисфункції - ми використовували процедуру побудови ROC-кривих - графік залежності чутливості від значення (1 - специфічність). Прогностичну силу тесту визначали за показником AUC (Area Under the Curve), враховуючи його ступінь відмінності від величини 0,5 (50 \%) (значення, яке свідчить про відсутність прогностичної сили). За стандарт порівняння використали результати, отримані при проведенні проби із ендотелійзалежною вазодилатацією. Було проаналізовано діагностичну цінність концентрації SPECAM-1 для верифікації дисфункції ендотелію в пробі з реактивною гіперемією. При підрахунку
AUC отримано діагностичну цінність результату $(77,3 \pm 6,18) \%(65,2-89,5 \%)$, р<0,001 при порівнянні з показником 50 \% (рис. 2).

Враховуючи отриману величину AUC можна стверджувати про достатньо високу діагностичну цінність приросту концентрації sPECAM-1 для діагностики ендотеліальної дисфункції. За ROCкривою, після аналізу розподілу чутливості та специфічності при різних концентраціях sPECAM-1 було визначено граничні концентрації для оцінки дисфункції ендотелію. Розподіл на «позитивні» та «негативні» результати вмісту молекули представлено у таблиці 5.

Використовуючи графічний режим (точка відсікання знаходиться у найближчому місці кри- 
Огляди літератури, оригінальні дослідження, погляд на проблему

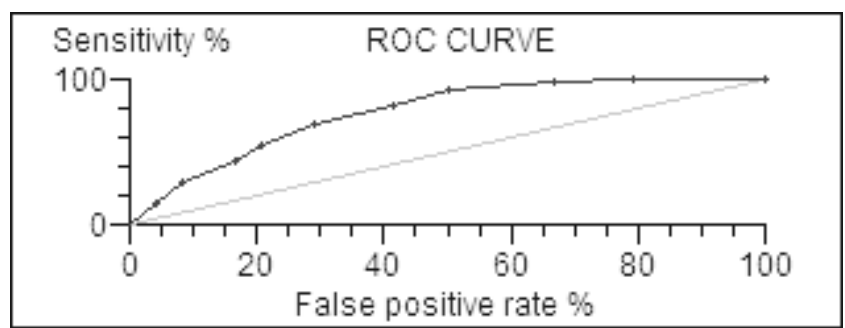

Рис. 2. ROC-крива для оцінки діагностичної цінності SPECAM-1 при верифікації дисфункції ендотелію.

Таблиця 5. Дихотомічний розподіл оцінки вмісту SPECAM-1 з урахуванням претестової вірогідності

\begin{tabular}{|c|c|c|c|c|}
\hline $\begin{array}{c}\text { Точка відсікання вмісту } \\
\text { SPECAM-1 }\end{array}$ & $\begin{array}{c}\text { Чутливість } \\
(\%)\end{array}$ & $\begin{array}{c}\text { Специфічність } \\
(\%)\end{array}$ & $\begin{array}{c}\text { Діагностичне відношення шансів } \\
\text { (Diagnostic OR, DOR) }\end{array}$ & $\begin{array}{c}\text { Індекс Йо- } \\
\text { дена (\%) }\end{array}$ \\
\hline 30,360 & 100,0 & 20,8 & - & 20,8 \\
\hline 40,536 & 98,2 & 33,3 & 27,5 & 31,5 \\
\hline 52,256 & 92,9 & 50,0 & 13,0 & 42,9 \\
\hline 60,420 & 82,1 & 58,3 & 6,4 & 40,5 \\
\hline 71,110 & 69,6 & 70,8 & 5,6 & 40,5 \\
\hline 81,900 & 55,4 & 79,2 & 4,7 & 34,5 \\
\hline 92,282 & 42,9 & 83,3 & 3,8 & 26,2 \\
\hline 104,666 & 28,6 & 91,7 & 4,4 & 20,2 \\
\hline 121,144 & 14,3 & 95,8 & 3,8 & 10,1 \\
\hline
\end{tabular}

вої відповідно до лівого верхнього кута графіка) було визначено оптимальну «точку», що дорівнювала величині вмісту SPECAM-1 на рівні 52,256 нг/мл. Цій же величині відповідав найвищий показник індексу Йодена (табл. 5).

Окрім цього, додатково було визначено коефіцієнти співвідношення 2:1 псевдонегативних результатів до псевдопозитивних і, навпаки, псевдопозитивних результатів до псевдонегативних, величини яких склали, відповідно, 40,536 та 52,256 нг/мл (табл. 6).

Обчислена посттестова вірогідність «істинно позитивного результату» для стратифікованих меж концентрації sPECAM-1 представлена в таблиці 6. Отже, фактично, найоптимальнішою величиною в якості «точки відсікання» для порушення ендотеліальної функції був вміст молекули адгезії sPECAM-1 на рівні 52,256 нг/мл.

Таблиця 6. Посттестова вірогідність та відношення шансів для меж коливань вмісту sPECAM-1

\begin{tabular}{|c|c|c|}
\hline $\begin{array}{c}\text { Межі вмісту SPECАМ-1 } \\
(\text { нг/мл) }\end{array}$ & $\begin{array}{c}\text { Відношення шансів } \\
\text { (95 \% ДІ) }\end{array}$ & $\begin{array}{c}\text { Посттестова вірогідність } \\
\text { на } 1000(95 \% \text { ДІ) }\end{array}$ \\
\hline $20,140-40,536$ & $0,14(0,05-0,40)$ & $250,0(106,8-481,8)$ \\
\hline $52,256-60,420$ & $1,11(0,45-2,78)$ & $722,2(510,4-866,4)$ \\
\hline $71,110-81,900$ & $2,14(0,68-6,72)$ & $833,3(614,4-940,1)$ \\
\hline $92,282-121,144$ & $2,57(1,00-6,61)$ & $857,1(700,0-939,1)$ \\
\hline
\end{tabular}

Висновки. 1. Встановлено вірогідний кореляційний зв'язок між концентрацією SPECAM-1, параметрами вуглеводного обміну та моделлю HOMA-IR.

2. На тлі підвищеної експресії тромбоцитарноендотеліальної молекули адгезії спостерігається істотне зниження коефіцієнтів розтяжності, відносної деформації, локальної жорсткості та збільшення швидкості розповсюдження пульсової хвилі.

3. При проведенні проби з ендотелійзалежною вазодилатацією встановлено позитивний зв'язок між концентрацією SPECAM-1 та величиною напруги зсуву, збільшенням вмісту молекули адгезії та зниженням чутливості до вазодилатації.

4. Визначено діагностичну цінність тромбоцитарно-ендотеліальної молекули адгезії sPECAM-1 щодо прогнозування дисфункції ендотелію у хворих на гіпертонічну хворобу з цукровим діабетом II типу, що дорівнює величині на рівні 52,256 нг/мл.

Перспективи подальших досліджень. У перспективі передбачається продовження досліджень тромбоцитарно-ендотеліальної молекули адгезії та її ролі в прогресуванні ускладнень у хворих на гіпертонічну хворобу з цукровим діабетом II типу. 
Огляди літератури, оригінальні дослідження, погляд на проблему

\section{ЛІТЕРАТУРА}

1. Лелюк В. Г. Ультразвуковая ангиология / В. Г. Лелюк, С. Э. Лелюк. - М. : Реальное время. - 2003. - 324 с.

2. Реброва О. Ю. Статистический анализ медицинских данных. Применение пакета прикладных программ STATISTICA / О. Ю. Реброва. - М. : Медиа-сфера. 2004. - 312 c.

3. Arterial Hypertension (Management of) ESC Clinical Practice Guidelines Reference / G. Mancia, R. Fagard, K. Narkiewicz [et al.] // Eur. Heart J. - 2013. - Vol. 34. P. 2159-2219.

4. Association of Leu125Val polymorphisms in the PECAM-1 gene with the risk of coronary heart disease: a meta-analysis / T. Xia, X. Liu, C. J. Du [et al.] // Int. J. Clin. Exp. Med. - 2015. - Vol. 8. - № 2. - P. 2219-2225.

5. ESC Guidelines on diabetes, pre-diabetes, and cardiovascular diseases developed in collaboration with the EASD. ESC Clinical Practice Guidelines Reference // L. Ryden, P. J. Grant, S. D. Anker [et al.] // Eur. Heart J. - 2013. Vol. 34. - P. 3035-3087.

6 . Flow shear stress differentially regulates endothelial uptake of nanocarriers targeted to distinct epitopes of PECAM-1 / J. Han, V. V. Shuvaev, P. F. Davies [et al.] // J. Control. Release. - 2015. - Vol. 210. - P. 39-47.

7. Intramembrane binding of VE-cadherin to VEGFR2 and VEGFR3 assembles the endothelial mechanosensory complex / B. G. Coon, N. Baeyens, J. Han [et al.] // J. Cell. Biol. - 2015. - Vol. 208. - № 7. - P. 975-986.

8. Non-invasive measurement of human endothelium dependent arterial responses: accuracy and reproducibility /
K. E. Sorensen, D. S. Celermajer, D. J. Spiegelhalter [et al.] // Br. Heart Jour. - 1995. - Vol. 74. - № 3. - P. 247-253.

9. Kato T. Blood pressure, renal biochemical parameters and histopathology in an original rat model of essential hypertension (SHRSP/Kpo strain) // T. Kato, N. Mizuguchi, A. Ito // Biomed. Res. - 2015. - Vol. 36. - № 3. P. $169-177$.

10. $P 2 Y_{2}$ and $G q / G_{11}$ control blood pressure by mediating endothelial mechanotransduction / S. Wang, A. Iring, B. Strilic [et al.] // J. Clin. Invest. - 2015. - Vol. 125. - № (8). P. 3077-3086.

11. Park S. PECAM-1 isoforms, eNOS and endoglin axis in regulation of angiogenesis / S. Park, C. M. Sorenson, N. Sheibani // Clin. Sci. (Lond). - 2015. - Vol. 129. - № 3. P. 217-234.

12. Platelet endothelial cell adhesion molecule-1 inhibits platelet response to thrombin and von Willebrand factor by regulating the internalization of glycoprotein Ib via AKT/glycogen synthase kinase-3/dynamin and integrin allbß3 / C. I. Jones, T. Sage, L. A. Moraes [et al.] // Arterioscler. Thromb. Vasc. Biol. - 2014. - Vol. 34. - № 9. P. 1968-1976.

13. Regulation of the endothelial apelin/APJ system by hemodynamic fluid flow/R. Busch, A. Strohbach, M. Pennewitz [et al.] // Cell Signal. - 2015. - Vol. 27. - № 7. - P. 1286-1296.

14. Sweet role of platelet endothelial cell adhesion molecule in understanding angiogenesis / S. Kitazume, R. Imamaki, K. Ogawa [et al.] // Glycobiology. - 2014. Vol. 24. - № 12. - P. 1260-1264.

\section{THROMBOCYTE-ENDOTHELIAL ADHESION MOLECULE AS PREDICTOR OF ENDOTHELIAL DYSFUNCTION AT ARTERIAL HYPERTENSION WITH DIABETES MELLITUS TYPE II}

\section{Higher State Educational Institution «Bukovynian State Medical University»}

๑Ye. I. Shorikov

SUMMARY. The role of thrombocyte-endothelial adhesion molecule SPECAM-1 in endothelial dysfunction in patients with arterial hypertension and diabetes mellitus type II is analysed in the article.

It was set the reliable correlation between the SPECAM-1 level, glycemia and insulin resistance index. The decline of tensility, elasticity, local inflexibility and increase of pulse wave were accompanied by forced expression of adhesion molecule. Positive correlation was verified between SPECAM-1 concentration and shear stress in endothelium dependent vasodilation, and, also, negative correlation between SPECAM-1 increasing and endothelium sensitivity in vasodilatation test. The diagnostic value of thrombocyte-endothelial adhesion molecule SPECAM-1 for endothelial dysfunction prognosis was analysed.

KEY WORDS: endothelial dysfunction, arterial hypertension, diabetes mellitus, adhesion molecule, sPECAM-1.

Отримано 09.11.2015 